\title{
Vaksineutvikling mot barnediaré i u-land
}

\section{Molekylær kartlegging av det varmestabile toksinet til E. coli legger til rette for rasjonell vaksinedesign.}

Årlig dør om lag en halv million barn i u-land av akutt diaré. I tillegg fører gjentatte diaréepisoder til underernæring, hemmet vekst og forsinket utvikling hos mange flere barn. Enterotoksigen Escherichia coli, en patogen variant av E. coli, er en av de viktigste årsakene til diaré hos barn i u-land. Enterotoksigen $E$. coli kan produsere to ulike toksiner: et varmestabilt og et varmelabilt. Enterotoksigen $E$. coli som produserer varmestabilt toksin forårsaker de fleste alvorlige formene for enterotoksigen $E$. coli-diaré blant barn i u-land, og vi har derfor konsentrert oss om å bidra til utviklingen av en vaksine mot dette.

Toksinet gir diaré ved å overaktivere en reseptor i tarmen som normalt reguleres av to peptider, guanylin og uroguanylin. Peptidene og reseptoren bidrar til å opprettholde normal væskebalanse i tarmen. Vårt vik- tigste funn er at det er en reell fare for at en vaksine mot det varmestabile toksinet kan generere antistoff som gir uønsket kryssreaksjon med disse humane peptidene. Men vi har også vist at det er mulig å danne antistoff som nøytraliserer det varmestabile toksinet uten å kryssreagere.

Vi har utført en detaljert molekylær kartlegging av det varmestabile toksinet som viser hvilke epitoper som kan gi opphav til trygge, ikke-kryssreagerende antistoffer, og hvilke deler av molekylet som bør muteres for å gjøre vaksinen ikke-toksisk. Denne informasjonen vil vi bruke til å konstruere en trygg og effektiv vaksine, som forhåpentligvis kan bli et viktig bidrag mot barnediaré.

\section{Arne Michael Taxt}

arne.taxt@uib.no

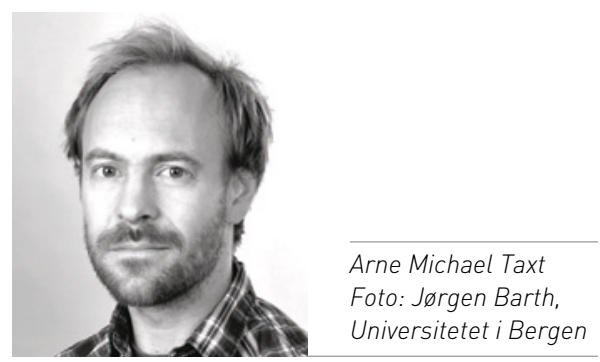

Disputas

Arne Michael Taxt disputerte for ph.d.-graden ved Universitetet i Bergen 5.10. 2015. Tittelen på avhandlingen er Characterisation of toxic, antigenic and cross-reactive determinants of the heat-stable toxin of enterotoxigenic Escherichia coli. Towards rational design of a toxoid vaccine.

\section{Kostholdsveiledning ved irritabel tarm-syndrom}

\section{Kostholdsveiledning kan forbedre symptomer og normalisere entero- endokrine celler hos pasienter med irritabel tarm-syndrom.}

Pasienter med irritabel tarm-syndrom relaterer symptomutvikling til maten de inntar. Symptomene bedrer seg etter at pasientene begynner på diett med lavt FODMAP(fermentbar oligo-, di-, monosakkarider og polyoler) inntak. Pasientene har unormale enteroendokrine celler i mage-tarm-systemet som kan bidra i utviklingen av sykdommen. Enteroendokrine celler frigjør hormoner som regulerer mage-tarm-funksjoner etter kontakt med mat. Målet vårt var å studere effekten av kostholdsveiledning på symptomer av irritabel tarm-syndrom og enteroendokrine celler.

14 pasienter ble inkludert og fikk tre økter med kostholdsveiledning om lav FODMAPdiett og endring i porsjoner av fett, protein og karbohydrater. Pasientene fikk spørreskjemaer om symptomer ved irritabel tarmsyndrom og livskvalitet før og etter kostholdsveiledningen. Gastroskopi og kolo- skopi med biopsier fra magesekk og tykktarm ble gjennomført før kostholdsveiledningen og igjen 3-9 (median 4) måneder etter veiledningen.

Før kostholdsveiledningen klaget pasientene over symptomer på irritabel tarm-syndrom og redusert livskvalitet. I tillegg hadde de forskjellige enteroendokrine cellene i magesekken og kolon unormale densiteter. Etter veiledningen bedret symptomene og livskvaliteten seg betydelig, og densiteten av forskjellig enteroendokrine celler i magesekken og kolon normaliserte seg.

Unormale enteroendokrine celler kan være en årsak til utvikling av irritabel tarmsyndrom. Kostholdsveiledning fører til normalisering av disse cellene og bedring av symptomer.

\section{Tarek Ramzi Elia Mazzawi}

tarek.ramzi.elia.mazzawi@helse-bergen.no

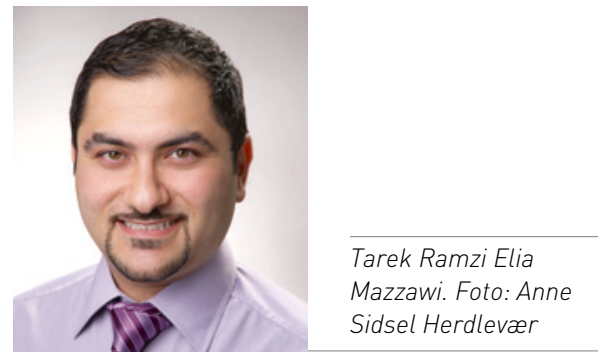

Disputas

Tarek Ramzi Elia Mazzawi disputerte for ph.d. graden ved Universitetet i Bergen 28.8. 2015. Tittelen på avhandlingen er The role of diet in irritable bowel syndrome with special reference to gut neuroendocrine system. 